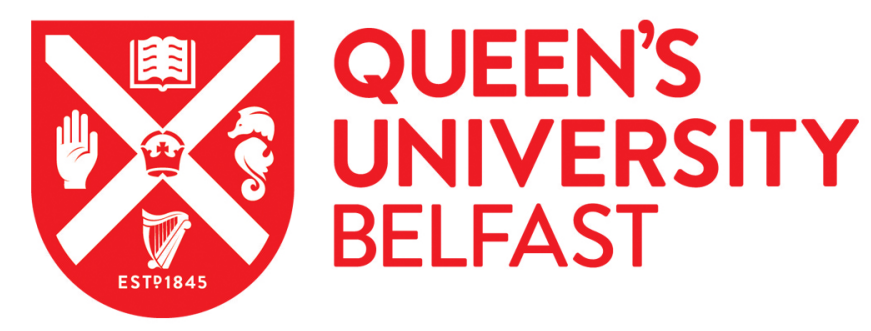

\title{
Identification of dermestid beetle modification on Neolithic Maltese human bone: Implications for funerary practices at the Xemxija tombs
}

Thompson, J. E., Martin-Vega, D., Buck, L. T., Power, R., Stoddart, S., \& Malone, C. (2018). Identification of dermestid beetle modification on Neolithic Maltese human bone: Implications for funerary practices at the Xemxija tombs. Journal of Archaeological Science Reports, 22, 123-131.

https://doi.org/10.1016/j.jasrep.2018.09.016

Published in:

Journal of Archaeological Science Reports

Document Version:

Peer reviewed version

Queen's University Belfast - Research Portal:

Link to publication record in Queen's University Belfast Research Portal

Publisher rights

(C) 2018 Elsevier Ltd.

This manuscript version is made available under the CC-BY-NC-ND 4.0 license http://creativecommons.org/licenses/by-nc-nd/4.0/,which permits distribution and reproduction for noncommercial purposes, provided the author and source are cited.

\section{General rights}

Copyright for the publications made accessible via the Queen's University Belfast Research Portal is retained by the author(s) and / or other copyright owners and it is a condition of accessing these publications that users recognise and abide by the legal requirements associated with these rights.

Take down policy

The Research Portal is Queen's institutional repository that provides access to Queen's research output. Every effort has been made to ensure that content in the Research Portal does not infringe any person's rights, or applicable UK laws. If you discover content in the Research Portal that you believe breaches copyright or violates any law, please contact openaccess@qub.ac.uk. 


\title{
Identification of dermestid pupal chambers to Neolithic Maltese human bone: implications for funerary practices at the Xemxija Tombs
}

\author{
Jess E. Thompson ${ }^{\mathrm{a},}$, Daniel Martín-Vega ${ }^{\mathrm{b}},{ }^{\mathrm{c}}$, Ronika K. Power $^{\mathrm{d}}$, Simon Stoddart $^{\mathrm{a}}$, Caroline Malone $^{\mathrm{e}}$ \\ ${ }^{a}$ Department of Archaeology, University of Cambridge, UK \\ ${ }^{\mathrm{b}}$ Departamento de Zoología y Antropología Física, Universidad de Alcalá, Spain \\ ${ }^{c}$ Department of Life Sciences, Natural History Museum, UK \\ ${ }^{\mathrm{d}}$ Department of Ancient History, Macquarie University, Australia \\ e School of Natural and Built Environment, Queen's University Belfast, Northern Ireland \\ ${ }^{*}$ Corresponding author: McDonald Institute of Archaeological Research, Downing Street, Cambridge, \\ CB2 3ER; jet71@cam.ac.uk
}

E-mail addresses: c.malone@qub.ac.uk (C. Malone); d.martin-vega@nhm.ac.uk (D. Martín-Vega); ss16@,cam.ac.uk (S. Stoddart); ronika.power@mq.edu.au (R. K. Power)

Suggested location: Journal of Archaeological Science (Impact Factor 2.6; 5000 word limit) https://www.elsevier.com/journals/journal-of-archaeological-science/0305-4403/guide-for-authors

\begin{abstract}
Taphonomic modification of Neolithic human skeletal remains from six rock-cut tombs in Malta have provided key information about funerary practices and the local environment. Application of microscopic analysis, computed tomography (CT) scanning, and 3D imaging of the modifications, has allowed their comparison with similar examples in modern and archaeological skeletal material. The modifications are interpreted as pupal chambers and feeding damage by dermestid beetles. Due to the behaviour and ecology of dermestid beetles, we suggest several scenarios for funerary practices at the Xemxija tombs which nuance our current understanding of collective burial during the late Neolithic in Malta.
\end{abstract}

Keywords: Archaeoentomology, dermestid beetles, funerary practices, human bones, Neolithic, taphonomy, Xemxija tombs.

\section{Introduction}

Modifications to human skeletal remains from archaeological contexts provide a wealth of information regarding individual health, cultural interactions with the remains of the dead, and the effects of the burial environment (White 1992, Haglund 1997a, 1997b, Andrews and Fernandez-Jalvo 2003, Ortner 2003a, Smith 2006, Duday 2009, Boz and Hager 2014, Robb et al. 2015). The latter two categories of taphonomic markers - cultural and natural modifiers to human remains following death and deposition - are sometimes juxtaposed, and there is debate as to whether natural modifications to skeletal remains can reveal cultural practices (cf. Knüsel and Robb 2016, 656). As the emerging field of funerary archaeoentomology is beginning to show, however, insect modifications to human skeletal remains allow us not only to reconstruct palaeoenvironments but also advance our understanding of funerary practices (Huchet and Greenberg 2010, Huchet et al. 2013, Huchet 2014a, 2014b, Matu et al. 2017). 
Among the non-anthropogenic modifiers of bone, rodents and carnivores have particularly been noted for their ability to disturb archaeological assemblages through feeding practices (Haglund 1997a, 1997b). Much less studied, however, are modifications to bone which result from insect activity such as feeding and the excavation of pupation chambers. Within the forensic sciences, insects provide crucial information to estimate the post-mortem interval as they are reliable ecological markers (Rodriguez and Bass 1983, Haskell et al. 1989, Wells and LaMotte 2001). Four orders of insects have been recognised as agents of bone modification, particularly on fossil dinosaur (Paik 2000, Roberts et al. 2007, Britt et al. 2008, Bader et al. 2009, Xing et al. 2013) and faunal remains (Martin and West 1995, Kaiser 2000, Holden et al. 2013). In the case of archaeological human remains, species identification due to the morphology of marks can aid the interpretation of funerary practices. In particular, dermestid beetles only colonise cadavers which are sub-aerially exposed and are known to thrive in warm environments with restricted light; thus, they can provide information regarding both the environmental and cultural circumstances of funerary practices (Huchet et al. 2013).

This paper presents the first analysis of entomological modification to human skeletal remains in the central Mediterranean from a series of six rock-cut tombs in northern Malta dating to the late Neolithic (Fig 1). The skeletal assemblage from the Xemxija rock-cut tombs contains a small number of fragmented bones which exhibit circular and ovate borings. Similar borings have been noted on human remains dating to the Middle Bronze Age in the Southern Levant (Huchet et al. 2013). At the rock-cut tombs of Jericho and Munhata, modifications were suggested to be the result of dermestid pupal chamber excavation, indicating a period of exposure and excarnation for a restricted number of individuals. Analysis of the beetle modifications to the Xemxija remains through microscopy and 3D imaging suggests different implications for funerary practices in Neolithic Malta.

\section{Material and Methods}

\subsection{Archaeological context}

The human bones discussed in this paper were excavated from a series of six rock-cut tombs in the Xemxija limestone plateau in northeast Malta (Fig 2). Excavations were carried out in 1955 by John Evans and a team of local workmen (Evans 1971). Despite Evans' excellent excavation record, details regarding the excavation methods employed at the Xemxija tombs have unfortunately not been published. Stratigraphically, most tombs were observed to have two fills: an upper brown clay layer and a lower deposit of white lime coloured with red ochre. In tombs 3 and 5, however, three fills were observed: an upper brown clayey horizon, a thin grey-white lime horizon and a base of compact red ochred earth (Evans 1971: 113). The lowest fill contained the main burial deposit, with pottery from multiple periods mixed in the upper fills.

Following excavation, the human skeletal remains seem to originally have been separated according to the tomb they were excavated from, but these distinctions have now been lost and the remains from all tombs are aggregated. Based on the typology of the pottery associated with the human remains, the burials were previously thought to date to the Ggantija phase (c.3600-3100 BC), during the late Neolithic period. Radiocarbon dates recently obtained 
from samples of tooth dentine from five left mandibular second molars show that the tombs were used for deposition from at least 3500-2450 cal BC (REF).

The chambers within each tomb are reached through a small entrance hole in the limestone plateau, which opens into dome-shaped burial chamber. The width of each tomb varies in size from $3.12 \mathrm{~m}-5.62 \mathrm{~m}$, with the roof height averaging only $1.25 \mathrm{~m}$ (Evans 1971, 113). The internal layout of each tomb varies, from one kidney-shaped burial chamber to three or five small lobed chambers radiating from the central entrance. Although each tomb is relatively small, some provided more internal distinctions in the burial space. Funerary practices during the late Neolithic period in Malta are characterised by collective burial in rock-cut tombs or caves (Malone et al. 2009, Sagona 2015). Primary inhumations, most likely of articulated individuals, are often found to be disturbed and fragmented by successive depositions.

Almost 15,000 fragments of human bone have been identified in the assemblage from the Xemxija tombs. A minimum number (MNI) of 100 individuals was determined, although due to the aggregation of the human remains, this is likely to significantly under-estimate the original burial population. All remains were noted to be highly fragmented and many displayed a variety of cortical surface modifications. A small number of fragments $(n=45)$ were observed to present circular or ovate borings ranging from c. $0.6-4 \mathrm{~mm}$ in diameter. Of this total, fifteen fragments were retained by one of the authors (JET) with the permission of the Superintendence of Cultural Heritage Malta for further analysis, presented below. ${ }^{1}$ These modifications were not noted in the original analysis of the human remains by Pike (1971).

\subsection{Microscopic analysis and 3D imaging}

The use of Computed Tomography (CT) and 3D imaging has greatly increased recently within the field of archaeology, and particularly within palaeoanthropology (Weber and Bookstein 2011, Uldin 2017). CT imaging is an excellent tool for non-destructive analysis, providing the means to view and manipulate fragile remains in digital space, aiding their conservation through the creation of a digital record which also allows for the reconstruction of fragmented remains (Lautenschlager 2016, Mahfouz et al. 2017). Further advantages include the ability to take accurate measurements and view surfaces which are usually obscured, such as the internal aspect of bones.

All fifteen fragments isolated from the Xemxija tombs assemblage were analysed using a Leica ${ }^{\circledR}$ M165 stereo microscope at the Natural History Museum (UK) and measurements were taken using Leica Application Suite EZ software (Leica Microsystems GmbH, Germany). Thirteen of these fragments were selected for CT-scanning with a Nikon Metrology XT H 225 ST at the Cambridge Biotomography Centre (UK). The CT-scans were made by Dr. Laura Buck and voxel sizes ranging from 0.06 to $0.12 \mu \mathrm{m} 3$ (to two decimal places) were selected as deemed appropriate. ${ }^{2}$ The specimen exhibiting the most well-defined pupal chambers was

\footnotetext{
${ }^{1}$ The human bones from the Xemxija tombs were curated at University College London, UK at the time of analysis, but were repatriated to the Superintendence of Cultural Heritage in Malta in 2017.

${ }^{2}$ Specimen 477 was scanned with voxel size 0.120614294245126 . Specimens 5273, 6626, 11074 and 11081 were scanned with voxel size 0.0751586481928825 . Specimens 5369, 5567, 8701 and 10048 were scanned with voxel size 0.067147759050179 . Specimens 8720,8895 and 10051 were scanned with voxel size 0.0633547706955909
} 
processed, with pupal chambers segmented and 3D visualisation generated, using Avizo 9.0 software (Visualization Sciences Group, Bordeaux, France) at the Natural History Museum.

\section{Description of the modifications}

All 45 fragments from the Xemxija tombs displaying circular or ovate borings represent less than $50 \%$ of the original skeletal element, indicating their high fragmentation. Only one fragment retains more than $50 \%$ of the original cortical surface, suggesting that taphonomic effects such as erosion, abrasion and weathering may have altered and truncated some surface modifications. Between 1 and c.70 marks are observed on each of these fragments. Modifications are present on cranial bones and long bones, most likely due to their composition of thick cortical bone which provides an ideal material for burrowing (Fig. 3). These burrows are noted on both internal/endocranial and external/ectocranial aspects of the skeletal elements, and occasionally they are truncated by post-depositional fragmentation. The circular and ovate borings are pseudopathological and could be mistaken for diseases involving focal osteoclastic activity, such as multiple myeloma or secondary carcinoma (Ortner 2003, 376). However, the borings exhibit regular well-defined edges, and are observed to occur in groups of a similar size (typically $1-4 \mathrm{~mm}$ in diameter). This is in common with excavation by insect mandibles, unlike the scalloped edges and irregular size of lytic lesions typically associated with myeloma.

Within the assemblage, specimen bags containing soil and pulverised chips of bone were present. These bags were carefully searched for any remains of the original trace-makers, but no evidence was found. As a result, the identification of the species which produced these modifications must proceed through categorisation of the marks, their morphology, and comparative analysis with modifications made by known insect species (Huchet 2014a). The modifications bear similarities to those described on fossil vertebrates and attributed to dermestid beetles (Martin and West 1995, Britt et al. 2008, Bader et al. 2009, Holden et al. 2013). Modification of human skeletal remains by dermestid beetles has recently been documented for the Bronze Age Levant (Huchet et al. 2013, 3796). Similarly, no evidence of the trace-makers was found, but the size and morphology of pupal chambers was found to be consistent with modern examples of dermestid pupal chambers in different materials (ibid.)

The fifteen fragments retained for analysis and described below were selected as they form a representative sample of this total. Following Britt et al. (2008), modifications on each of the fifteen fragments retained from the Xemxija tombs have been categorised according to the morphology of marks into three types: pits, bores and furrows (Table 1). Britt et al. (2008) also record grooves, which are shallow paired scratches made by mandibles as a result of gnawing. However, these are not visible on most of the analysed specimens from the Xemxija tombs due to the poor preservation of bone cortices and this category has thus been eliminated from this study. Pits are defined as hemispherical excavations that do not have parallel sides (Fig. 4a) and are distinguished from shallow pits which are less than $0.5 \mathrm{~mm}$ in depth. Shallow pits are sometimes referred to as incipient pits, and have been linked to practices of feeding on bone (Zanetti et al. 2014). Bores do have parallel sides and represent internal mining of the bone for pupation chambers (Fig. 4b,c); they are divided into shallow $(<5 \mathrm{~mm})$ and deep $(5<\mathrm{mm})$ varieties. Furrows are the result of external mining and resemble meandering channels on the surface of the bone (Fig. 4d). 
The cortical preservation of each element has been scored on a scale from $0-5$ using the Qualitative Bone Index (QBI), where $0=0 \%, 1=1-24 \%$, 2=25-49\%, 3=50-74\%, 4=75-99\%, $5=100 \%$ (Bello 2005). All specimens display poor preservation of cortical surfaces which affects the visibility of taphonomic modifications. Although it is possible that some cortical degradation is a result of beetle activity such as incipient boring, it is not possible to assess this due to the high level of erosion across the assemblage. Furrows were observed on only two of the fifteen analysed fragments and, as discussed, their preservation may have been compromised due to cortical erosion and abrasion. Modifications on the internal aspects of bones are often observed alongside external modifications. Only in one case (XEM11074) is a single shallow bore observed, in this case on the internal aspect; however, since we are unable to observe the complete element it is possible that external modifications were originally present.

\begin{tabular}{|l|l|l|l|l|l|}
\hline $\begin{array}{l}\text { Specimen } \\
\text { Number }\end{array}$ & Element & QBI & Pit & Bore & Furrow \\
\hline XEM477 & Femur & 1 & - & X (E) & X (E) \\
\hline XEM5273 & Parietal & 1 & - & X (E) & - \\
\hline XEM5368 & Long bone & 3 & X (I) & X (I \& E) & - \\
\hline XEM5369 & Femur & 1 & X (E) & X (E) & - \\
\hline XEM5567 & Femur & 0 & X (E) & X (E) & - \\
\hline XEM6626 & $\begin{array}{l}\text { Cranial } \\
\text { fragment }\end{array}$ & 1 & X (I \& E) & X (I \& E) & - \\
\hline XEM8701 & Femur (L) & 0 & X (E) & - & - \\
\hline XEM8720 & Femur & 0 & X (E) & X (E) & - \\
\hline XEM8892 & Long bone & 1 & X (E) & X (I \& E) & - \\
\hline XEM8893 & Long bone & 0 & - & $X(E)$ & - \\
\hline XEM8895 & Long bone & 0 & X (I \& E) & X (E) & - \\
\hline XEM10048 & Long bone & 0 & X (E) & X (E) & X (E) \\
\hline XEM10051 & $\begin{array}{l}\text { Humerus } \\
\text { R) }\end{array}$ & 0 & X (E) & X (E) & - \\
\hline XEM11074 & $\begin{array}{l}\text { Cranial } \\
\text { fragment }\end{array}$ & 2 & - & $X(I)$ & - \\
\hline XEM11081 & $\begin{array}{l}\text { Cranial } \\
\text { fragment }\end{array}$ & 0 & - & $X(E)$ & - \\
\hline
\end{tabular}


Table 1: Modifications observed as a result of beetle activity ( $\mathrm{X}=$ present; - = absent; $\mathrm{E}=$ external/ectocranial; I= internal/endocranial).

Measurements were taken of the maximum diameters of pits and bores across three fragments (Table 2). The mean diameter of the modifications is slightly below the mean noted for dermestid pupal chambers from archaeological and modern samples, as reported by Huchet et al. $(2013,3796)$. Despite this, we believe that dermestid beetles are the most likely agent of the modifications due to the consistent morphology of the pits and bored. The modifications are noted to have well-defined, regular margins and are of a similar size on each specimen. The smaller average size of pupal chambers on skeletal remains from the Xemxija tombs may be explained with reference to dermestid feeding patterns, with incipient pits resulting from feeding on bone, or simply as initial attempts to excavate bores.

The specimen exhibiting the most well-defined pupal chambers (XEM8720) was reconstructed in $3 \mathrm{D}$ with a majority of the chambers segmented in order to more clearly define their morphology (Figures 5 and 6). The pupal chambers isolated on this specimen are mostly ovate borings of irregular depth (Figure 7). It is possible that many of the shallow borings, which have been classified as pits, in fact represent the base of the pupal chamber if it was originally excavated in dried tissue (see Huchet et al. 2013, 3800).

\begin{tabular}{|r|r|r|l|l|}
\hline $\begin{array}{l}\text { Specimen } \\
\text { number }\end{array}$ & $\begin{array}{l}\text { Diameter 1 } \\
(\mathbf{m m})\end{array}$ & $\begin{array}{l}\text { Diameter 2 } \\
(\mathbf{m m})\end{array}$ & $\begin{array}{l}\text { Depth } \\
\mathbf{( m m})\end{array}$ & Type \\
\hline XEM477 & 0.627 & 0.842 & & Pit \\
\hline XEM477 & 0.667 & 0.822 & & Pit \\
\hline XEM477 & 1.135 & 1.139 & & Pit \\
\hline XEM8720 & 2.567 & 2.269 & & Pit \\
\hline XEM8720 & 2.889 & 2.928 & & Pit \\
\hline XEM8720 & 2.572 & 2.885 & & Pit \\
\hline XEM8720 & 3.972 & 3.655 & & Pit \\
\hline XEM8895 & 3.314 & 3.771 & 9.445 & Bore \\
\hline XEM8895 & 3.07 & 4.086 & 9.128 & Bore \\
\hline XEM8895 & 3.899 & - & & Pit \\
\hline Mean & 2.471 & 2.488 & & \\
\hline
\end{tabular}

Table 2: Measurements across maximum diameter of pits, and diameter and depth of bores, from three specimens.

\section{Insects as taphonomic modifiers}

Traces of entomofauna in association with human remains are of critical importance in forensic contexts to refine the estimation of the post-mortem interval (PMI). Cadavers are colonised by the larvae of necrophagous insects that consume dead tissues to complete their development. Thus estimation of the age of the immature insects collected on a cadaver can provide a minimum PMI (Wells and LaMotte 2001). Typically, flies colonise a cadaver first, and will be succeeded by beetles, although factors such as the environment, season of death, and the condition and location of the body may change the pattern of succession (Vanin and 
Huchet 2017, 173). A positive correlation has been noted between temperature and developmental rate in insects, whereby their survival often depends upon the maintenance of an optimum temperature range (Martín-Vega et al. 2017, Vanin and Huchet 2017).

Archaeologically, evidence of this process of insect colonisation has particularly been detected in cases of mummified individuals. Analysis of insect larvae can refine the season of death (Vanin and Huchet 2017). In the case of a Chachapoya mummy, remains of a number of insect species were present within preserved brain tissue and the mummy wrappings (Nystrom et al. 2005). The succession phases of the species present, alongside palaeopathological analysis, suggested that the individual had died 10-12 days after suffering cranial trauma and trepanation, during which time the open wounds attracted Diptera and parasitoid Hymenoptera and an osseous response to the trauma was initiated. The evidence suggested that the individual was wrapped soon after death. Insect species identification thus has the potential to provide a reconstruction of funerary rites and, in exceptional cases, the final stages of an individual's life.

When only skeletonised remains are present, as in this study, analysis of insect activity relies upon traces left on bones. These traces typically take the form of bores, burrows and gnaw marks and are attributed to only four orders of insects which are known to modify human bone (Vanin and Huchet 2017). These comprise Isoptera (subterranean termites) which tunnel and gnaw both buried and exposed bone, Coleoptera (beetles) which preferentially feed on subaerially exposed dried muscle tissues, Hymenoptera (wasps and burrowing bees) which may construct nesting galleries in bones, and Diptera (sarco-saprophagous fly larvae) which can erode bone through their acidic digestive juices (Pittoni 2009, Backwell et al. 2012, Huchet 2014b, Vanin and Huchet 2017).

\section{Dermestid beetles}

With over 1200 species distributed among 45 genera (Háva 2003), beetles of the family Dermestidae have a major negative impact as a pest of stored animal products (Fontenot et al. 2015). Among the Dermestidae, species within the genus Dermestes Linnaeusare of particular economic importance as they can infest a wide range of stored proteinaceous products and foods for human consumption (Fontenot et al. 2015). Moreover, most species within the genus Dermestes are scavengers during both the adult and larval stages (Zhantiev 2009). Dermestid beetles are frequently collected in association with sub-aerially exposed cadavers in advanced stages of decomposition, feeding on dry skin and dessicated tissues. Therefore, dermestids are potentially useful indicators in both forensic and archaeological investigations concerning skeletonised or mummified remains (Huchet et al. 2013, Charabidze et al. 2014, Vanin and Huchet 2017).

While over 1200 species of dermestids have been identified, only nineteen have been recorded on the Maltese islands (Háva 2003, Háva and Mifsud 2006). These include three of the most common outdoor species in the Mediterranean region (Háva 2006, Martín-Vega and Baz 2012): Dermestes maculatus De Geer, Dermestes frischii Kugelan and Dermestes undulatus Brahm. These species are also among the small number which have been directly observed on human remains (Charabidze et al. 2014). Usually, only one species of dermestid is observed on a single corpse, but $D$. undulatus and D. frischii are occasionally found together (ibid.). 
Dermestid larvae thrive in warm and dry environments, actively avoiding both excessive light and humidity (Charabidze et al. 2014). Studies have shown that dermestid larvae survival is highest when temperatures are between $20-30^{\circ} \mathrm{C}$ and their period of activity is restricted to the warmest months of the year (Amos 1968, Raspi and Antonelli 1996, Zanetti et al. 2016a, 2016b, Martín-Vega and Baz 2012, Martín-Vega et al. 2017). Thus, their presence can indicate seasonality. Temperature can also significantly affect the duration of the larval stage, which can vary from 26.8 to 78.8 days, with a colder temperature requiring a longer period of pupation (Martín-Vega et al. 2017, 1143). Under optimal, warm and dry conditions, dermestid adults and larvae can therefore appear in large numbers, greatly accelerating the process of skeletonisation of a cadaver (Schroeder et al. 2002, Charabidze et al. 2014). Those situations of close proximity of conspecifics also predispose dermestids to cannibalism, mainly of pupae by larvae (Archer and Elgar 1998, Fontenot et al. 2015).

During the pupal stage, the insect undergoes metamorphosis and becomes quiescent, thus being highly vulnerable. Because of this, when a mature larva ceases feeding, it searches actively for a safe place to pupate, usually excavating a protective pupation chamber into the most appropriate nearby material (Archer and Elgar 1998, Fontenot et al. 2015). Although pupal chambers are frequently bored away from food sources, dermestid larvae can bore into meat or carrion substrate, sometimes even perforating the underlying bone (Martin and West 1995, Archer and Elgar 1998). In this case, because the dessicated tissue decays later, pupal chambers are usually found as partial casts of different depths in the bone, rather than complete burrows (Martin and West 1995, Huchet et al. 2013). Dermestid pupal chambers have been found, within both archaeological and palaeontological contexts, on bones from a range of vertebrates, including humans (Martin and West 1995, Britt et al. 2008, Huchet et al. 2013). In the case of human cadavers, the preferential feeding areas for dermestids are said to be the face, hands and feet but the excavation of pupation chambers is opportunistic and will not necessarily follow this pattern (Charabidze et al. 2014).

The excavation of pupal chambers provides information not only on the local ecology and environment, but also has implications for funerary practices. Dermestids are known to colonise remains which are exposed, indicating that skeletal remains with evidence of dermestid modification were not covered with earth and buried. Charabidze et al. (2014) note that dermestid pupation chambers in bone have not been recorded in forensic cases, nor in instances where dermestids have been selectively used to deflesh human remains. This may be because softer materials such as paper and wood were more readily available, as providing pupation substrates is a common practice in the management of dermestid laboratory colonies to minimise mortality due to cannibalism (Fontenot et al. 2015). Experimental studies on mummified rats in Egypt have shown conclusively that dermestid larvae excavate pupation chambers in dried tissues and bone (Abdel-Maksoud et al. 2011). Dermestid pupal chambers usually occur in clusters and, when they appear on bones, may indicate a situation of stress with limited availability of both food and pupation substrates (Roberts et al. 2003). As mentioned above, it has been suggested that the morphology of pupation chambers is linked to whether remains are fleshed or skeletonised at the time of their excavation. Huchet et al. (2013, 3800) have argued that pupation chambers excavated in fleshed remains will only leave a trace of the base of the chamber, in the form of shallow and narrow pit in the bone. When skeletonised remains are burrowed, the bore hole is likely to be both larger and deeper. 
Moreover, when little dry tissue is available on skeletonised remains, dermestid beetles start to eat the bones themselves, leaving pits and mandible marks on the bone surface (Zanetti et al. 2014).

\section{Reconstructing funerary practices at the Xemxija tombs}

As discussed above, dermestid feeding patterns affect the morphology of marks made on human bone. A small number of human remains from the Xemxija tombs present pits and bores of varying size and depth which we have attributed to dermestid beetles. The smaller average size of the modifications on the Xemxija assemblage may be related to dermestid feeding patterns. Shallow pits, with a diameter between $2-5 \mathrm{~mm}$, have been explained by Huchet et al. $(2013,3800)$ as the remnants of a pupal chamber which was originally excavated in dried tissue. Much smaller pits, however, are seen on the Xemxija remains. Circular pits measuring between $0.6-1.4 \mathrm{~mm}$ in diameter were observed on six of the fifteen specimens included in this study, on both the internal and external aspects of the bone. Dermestid beetles have never been observed to penetrate the medullary cavity of decomposing remains; thus, the few specimens presenting internal modifications were most likely already fragmented prior to colonisation. This suggests that dermestid beetles colonised both fleshed and defleshed remains in the Xemxija tombs. Similarities may be drawn with these small pits and the incipient pits noted by Zanetti et al. $(2014,999)$ due to dermestid feeding on bones. Another possibility, put forth by Huchet et al. $(2013,3800)$, is that incomplete borings may represent the initial stages of pupal chamber excavations that were abandoned.

As evidence for funerary practices, these insights suggest a number of possibilities. We present three scenarios for funerary practices at the Xemxija tombs which resulted, in a small number of cases, in osseous modifications due to dermestid colonisation. These scenarios are not mutually exclusive:

1. A restricted period of exposure for some individuals prior to their deposition.

2. Interred corpses deposited on the ground surface of chambers and disturbed by successive interments.

3. Rearrangement and redistribution of the remains of previous interments, including the movement of some bones outside of the chamber, before their re-deposition.

The first scenario suggests that dermestids were only able to access a small number of corpses, implying that funerary practices may have differed perhaps according to the time or circumstances of death, or in relation to individual identity. Furthermore, it is likely that the exposure of corpses would result in accompanying taphonomic damage, such as carnivore gnaw marks, which are not present on this assemblage. The second scenario assumes that dermestid beetles were present in tomb chambers and were therefore able to colonise the fleshed remains of recent interments as well as the skeletonised remains of earlier inhumations. The final scenario presents a model of movement of some remains outside of the chamber, during which time dermestids could colonise the skeletal material.-

The first model, of exposure and excarnation of a small number of individuals, is suggested by Huchet et al. (2013) as the explanation for dermestid modifications on the Jericho and Munhata remains. Larger and more consistently-sized pupal chambers were observed in those cases than on the remains from the Xemxija tombs. Furthermore, exposed corpses invite 
a range of other scavengers which can leave traces on skeletal remains (cf. Haglund 1997a, 1997b). No evidence of carnivore or rodent gnawing has been identified on the Xemxija tombs assemblage, nor on the skeletal remains from the Xaghra Circle, the only other contemporary burial site to have been recently analysed (Stoddart et al. 2009). The evidence at the Xemxija tombs for mining on the internal surface of bones, and on fragmented bones, further discounts this model.

The small number of fragments displaying dermestid modifications may seem to challenge the hypothesis that dermestids were present within the tombs. It is possible, however, that other surface modifications such as mandible groove marks were present on many more fragments than have been identified. The high level of cortical surface erosion and abrasion noted across the human remains is likely to have suppressed the visibility of these. As previously mentioned, dermestid beetles only rarely excavate pupation chambers in bone. It is therefore possible that on other occasions, a more suitable pupation substrate was available. The temperature and condition within the tombs is amenable to dermestid habitation, as they are both cool and dark. As a result, the tomb/s would only reach the optimal temperature for the dermestid larval cycle for a restricted period, with pupation chambers likely indicating activity during the hottest part of summer. A model of successive inhumation of fleshed remains over previous interments, in various stages of decomposition and skeletonisation, would have provided the opportunity for dermestid beetles to colonise dessicated tissues and bones for both subsistence and pupation substrate.

The movement of skeletal remains outside of chambers, as suggested in the third model, cannot be conclusively proven with taphonomic evidence. The high level of fragmentation may support this hypothesis but can also be explained by successive inhumation in the model presented above. However, this model finds support in the evidence for redistribution of skeletal remains at contemporary burial sites. At the Kercem rock-cut tomb on Gozo, disarticulated skeletal remains were found at the edges of the chamber, having been cleared to make space for a primary inhumation (Times of Malta 2009). The highly commingled and disarticulated skeletal assemblage at the Xaghra Circle suggests there may be precedence for the movement of remains outside of spatially discrete areas (Malone et al. 2009).

We suggest that the most parsimonious model is that individuals were interred in the Xemxija tombs soon after death and bodies were not covered with sediment. Dermestids were present on the ground surface and may also have been present within tombs. They were therefore able to colonise the remains of recently interred individuals and prior depositions, and were also able to exploit remains if they were removed from the chamber. In exceptional cases, when other pupation substrates were unavailable and during optimal temperature conditions, pupation chambers were excavated within both fleshed remains and surrounding fragmented human bones. When the environment was particularly nutrient-poor, dermestids may have fed on the bones themselves, leaving evidence in the form of incipient pits.

\section{Conclusion}

Modifications arising from insect activity are likely to be much more common on archaeological human remains than is typically recognised. However, as funerary 
archaeoentomology remains in its infancy, there is only a small pool of case studies to draw on for comparative analysis. Insect pupal cases are resistant to decay and, in circumstances of excellent preservation, may be recovered in archaeological contexts (e.g. Huchet and Greenberg 2010). Even where preservation conditions are not optimal, however, traces of pupal chambers may be left in osseous material. As we hope to have shown, their identification is significant in the reconstruction of the local environment, furthering our understanding of species ecology and behaviour, and can also have implications for funerary practices.

Dermestid modification to a small number of human bones from the Xemxija tombs is consistent with current interpretations of late Neolithic funerary practices in Malta. Collective burials during the Neolithic in Malta are characterised by their long duration. Centuries of successive depositions facilitated extensive rearrangement and commingling. In the context of the rock-cut tombs at Xemxija, this provided the opportunity for dermestid beetles to exploit both fleshed and defleshed remains.

\section{Acknowledgements}

We are grateful to Rachael Sparks, keeper of collections at University College London, UK, for granting access to the material from the Xemxija tombs. We are also indebted to Sharon Sultana, senior curator at the National Museum of Archaeology, Malta, and the Superintendence of Cultural Heritage, Malta, for their permission to undertake scientific analyses on this material.

Funding: This research was undertaken as part of an ERC Advanced Grant, Grant Number 323727 "FRAGSUS" 2013-18 Ideas Specific FP7 programme, led by the Principal Investigator Caroline Malone on behalf of the extended research team. This research was also funded by the AHRC (grant number XXXX) and Magdalene College, Cambridge (Thompson). This publication is Number XXXX of the Project Series reporting on the work of the FRAGSUS Project.

\section{Bibliography}

Abdel-Maksoud, G., Al-Shazly, E.E.A.A.-S., and E-Amin, A.R., 2011. Damage caused by insects during the mummification process: an experimental study. Archaeological and Anthropological Sciences, 3 (3), 291-308.

Amos, T.G., 1968. Some laboratory observations on the rates of development, mortality and oviposition of Dermestes frischii (Kug.) (Coleoptera, Dermestidae). Journal of Stored Products Research, 4, 103-117.

Andrews, P. and Fernandez-Jalvo, Y., 2003. Cannibalism in Britain: taphonomy of the Creswellian (Pleistocene) faunal and human remains from Cough's Cave (Somerset, England). Bulletin of the Natural History Museum London (Geology), 58, 59-81.

Applbaum, N. and Applbaum, Y.H., 2005. The Use of Medical Computed Tomography (CT) Imaging in the Study of Ceramic and Clay Archaeological Artifacts from the Ancient Near East. In: M. Uda, G. Demortier, and I. Nakai, eds. X-rays for Archaeology. Heidelberg: Springer, 231-245. 
Archer, M.S., and Elgar, M.A., 1998. Cannibalism and delayed pupation in hide beetles, Dermestes maculatus DeGeer (Coleoptera: Dermestidae). Australian Journal of Entomology, 37, 158-161.

Backwell, L.R., Parkinson, A.H., Roberts, E.M., D’Errico, F., and Huchet, J.-B., 2012. Criteria for identifying bone modification by termites in the fossil record. Palaeogeography, Palaeoclimatology, Palaeoecology, 337-338, 78-87.

Bader, K.S., Hasiotis, S.T., and Martin, L.D., 2009. Application of forensic science techniques to trace fossils on dinosaur bones from a quarry in the Upper Jurassic Morrison Formation, northeastern Wyoming. PALAIOS, 24, 140-158.

Bello, S., 2005. The reciprocal effects of taphonomy, funerary practices and anatomical features of the state of preservation of human remains. In: S.R. Zakrzewski and M. Clegg, eds. Proceedings of the 5th Conference of the BABAO. Oxford: BAR International Series 1383, 1-10.

Boz, B. and Hager, L.D., 2014. Making Sense of Social Behaviour from Disturbed and Commingled Skeletons: A Case Study from Catalhoyuk, Turkey. In: A.J. Osterholtz, K.M. Baustian, and D.L. Martin, eds. Commingled and Disarticulated Human Remains: Working Toward Improved Theory, Method and Data. London: Springer, 17-33.

Britt, B.B., Scheetz, R.D., and Dangerfield, A., 2008. A Suite of Dermestid Beetle Traces on Dinosaur Bone from the Upper Jurassic Morrison Formation, Wyoming, USA. Ichnos, 15 (2), 59-71.

Charabidze, D., Colard, T., Vincent, B., Pasquerault, T., and Hedouin, V., 2014. Involvement of larder beetles (Coleoptera: Dermestidae) on human cadavers: a review of 81 forensic cases. International Journal of Legal Medicine, 128 (6), 1021-30.

Duday, H., 2009. The Archaeology of the Dead: Lectures in Archaeothanatology. Oxford: Oxford University Press.

Evans, J., 1971. The prehistoric antiquities of the Maltese islands: a survey. London: Athlone Press.

Fontenot, E.A., Arthur, F.H., and Hartzer, K.L., 2015. Effect of diet and refugia on development of Dermestes maculatus DeGeer reared in a laboratory. Journal of Pest Science, 88, $113-119$.

Galdies, C., 2011. The Climate of Malta: statistics, trends and analysis 1951-2010. Malta.

Haglund, W.D., 1997a. Dogs and Coyotes: Postmortem Involvement with Human Remains. In: W.D. Haglund and M. Sorg, eds. Forensic Taphonomy: The Postmortem Fate of Human Remains. Boca Raton: CRC Press, 367-382.

Haglund, W.D., 1997b. Rodents and human remains. In: W.D. Haglund and M. Sorg, eds. Forensic Taphonomy: The Postmortem Fate of Human Remains. Florida: CRC Press, 405-414.

Haskell, N.H., McShaffrey, D.G., Hawley, D.A., Williams, R.E., and Pless, J.E., 1989. Use of aquatic insects in determining submersion interval. Journal of forensic sciences, 34 (3), 622-32.

Háva, J., 2003. World Catalogue of the Dermestidae (Coleoptera). Studie a zprávy Oblastniho Muzea Praha-východ v Brandýse nad Labem a Staré Boleslavi, Supplement, 1-196. 
Háva, J. and Mifsud, D., 2006. The dermestid beetles (Coleoptera: Dermestidae) of the Maltese Archipelago (Central Mediterranean). Studies and reports of District Museum Prague-East. Taxonomical Series., 2 (1-2), 51-63.

Holden, A.R., Harris, J.M., and Timm, R.M., 2013. Paleoecological and taphonomic implications of insect-damaged pleistocene vertebrate remains from Rancho La Brea, Southern California. PLoS One, 8 (7), e67119.

Huchet, J.-B., 2014a. Approche ichnologique et taphonomique des alterations ostéolytiques dues aux insectes en contexte archéologique. In: Denys, C., PatouMathis, M. (Eds.), Manuel de Taphonomie. Muséum National d'Histoire Naturelle CNRS, Errance, Paris, pp. 185-207.

Huchet, J.-B., 2014b. Insect remains and their traces: relevant fossil witnesses in the reconstruction of past funerary practices. Anthropologie, LII (3), 329-346.

Huchet, J.-B. and Greenberg, B., 2010. Flies, Mochicas and burial practices: a case study from Huaca de La Luna, Peru. Journal of Archaeological Science, 37, 2846-2856.

Huchet, J.-B., Le Mort, F., Rabinovich, R., Blau, S., Coqueugniot, H., and Arensburg, B., 2013. Identification of dermestid pupal chambers on Southern Levant human bones: inference for reconstruction of Middle Bronze Age mortuary practices. Journal of Archaeological Science, 40, 3793-3803.

Kaiser, T.M., 2000. Proposed fossil insect modification to fossil mammalian bone from PlioPleistocene hominid-bearing deposits of Laetoli (Northern Tanzania). Annals of the Entomological Society of America, 93, 693-700.

Knüsel, C.J. and Robb, J., 2016. Funerary taphonomy: An overview of goals and methods. Journal of Archaeological Science: Reports, 10, 655-673.

Lautenschlager, S., 2016. Reconstructung the past: methods and techniques for the digital restoration of fossils. Royal Society Open Science, 3, 160342.

Mahfouz, M.R., Mustafa, A., Elhak, E., Fatah, A., Herrmann, N.P., and Langley, N.R., 2017. Computerized reconstruction of fragmentary skeletal remains. Forensic Science International, 275, 212-223.

Malone, C., Stoddart, S., Trump, D., Bonanno, A., Gouder, T., and Pace, A., 2009. Mortuary Customs in Prehistoric Malta: Excavations at the Brochtorff Circle at Xaghra (19871994). Cambridge: McDonald Institute for Archaeological Research.

Martín-Vega, D., and Baz, A., 2012. Spatiotemporal distribution of necrophagous beetles (Coleoptera: Dermestidae, Silphidae) assemblages in natural habitats of central Spain. Annals of the Entomological Society of America, 105, 44-53.

Martín-Vega, D., Díaz-Aranda, L.M., Baz, A., and Cifrián, B., 2017. Effect of temperature on the survival and development of three forensically relevant Dermestes species (Coleoptera: Dermestidae). Journal of Medical Entomology, 54 (5), 1140-1150.

Martin, L.D. and West, D.L., 1995. The recognition and use of dermestid (Insecta, Coleoptera) pupation chambers in paleoecology. Palaeogeography, Palaeoclimatology, Palaeoecology, 113, 303-310.

Matu, M., Crevecoeur, I., and Huchet, J.-B., 2017. Taphonomy and Paleoichnology of Olduvai Hominid 1 (OH1), Tanzania. International Journal of Osteoarchaeology, 27 (5), 785-800. 
Nystrom, K.C., Goff, A., and Lee Goff, M., 2005. Mortuary Behaviour Reconstruction through Palaeoentomology: A Case Study from Chachapoya, Perú. International Journal of Osteoarchaeology, 15, 175-185.

Ortner, D.J., 2003. Identification of pathological conditions in human skeletal remains. London: Academic Press.

Paik, I.S., 2000. Bone chip-filled burros associated with bored dinosaur bone in floodplain paleosols of Cretaceous Hasandong Formation, Korea. Palaeogeography, Palaeoclimatology, Palaeoecology, 157, 213-225.

Pike, G., 1971. The human bones from the Xemxija tombs. In: J. Evans, ed. The prehistoric antiquities of the Maltese islands: a survey. London: Athlone Press, 236-238.

Pittoni, E., 2009. Necropoli of Pill'e Matta Quartucciu (Cagliari, Sardinia): Wild Bee and Solitary Wasp Activity and Bone Diagenetic Factors. International Journal of Osteoarchaeology, 19, 386-396.

Raspi, A. and Antonelli, R., 1996. Influence of constant temperature on the development of Dermestes maculatus. Frustula Entomology, 18, 169-176.

Robb, J., Elster, E.S., Isetti, E., Knüsel, C.J., Tafuri, M.A., and Traverso, A., 2015. Cleaning the dead: Neolithic ritual processing of human bone at Scaloria Cave, Italy. Antiquity.

Roberts, E.M., Rogers, R.R., and Foreman, B.Z. 2003. An experimental approach to identifying and interpreting dermestid (Insecta, Coleoptera) bone modification. Journal of Vertebrate Paleontology, 23, 89A-90A.

Roberts, E.M., Rogers, R.R., and Foreman, B.Z., 2007. Continental insect borings in dinosaur bone: examples from the late Cretaceous of Madagascar and Utah. Journal of Paleontology, 81 (1), 201-208.

Rodriguez, W.C. and Bass, W.M., 1983. Insect Activity and its Relationship to Decay Rates Of Human Cadavers in East Tennessee. Journal of Forensic Sciences, 28 (2), 423-432.

Sagona, C., 2015. The Archaeology of Malta: From the Neolithic through the Roman Period.

New York: Cambridge University Press.

Schroeder, H., Klotzbach, H., Oesterhelweg, L., and Püschel, K., 2002. Larder beetles (Coleoptera, Dermestidae) as an accelerating factor for decomposition of a human corpse. Forensic Science International, 127, 231-236.

Smith, M., 2006. Bones chewed by canids as evidence for human excarnation: a British case study. Antiquity, 80, 671-685.

Stoddart, S., Barber, G., Duhig, C., Mann, G., O’Connell, T., Lai, L., Redhouse, D., Tykot,

R.H., and C., M., 2009. The Human and Animal Remains. In: C. Malone, S.Stoddart.,

D.Trump., A. Bonanno, T. Gouder, and A.Pace., eds. Mortuary Customs in Prehistoric

Malta: Excavations at the Brochtorff Circle at Xaghra (1987-1994). Cambridge:

McDonald Institute for Archaeological Research, 315-340.

Times of Malta, 2009. 5000 year-old tombs under study in Kercem, 10 Oct.

Uldin, T., 2017. Virtual anthropology - a brief review of the literature and history of computed tomography. Forensic Sciences Research.

Vanin, S. and Huchet, J.-B., 2017. Forensic Entomology and Funerary Archaeoentomology. In: E.M. Schotsmans, N. Márquez-Grant, and S. Forbes, eds. Taphonomy of Human Remains: Forensic Analysis of the Dead and the Depositional Environment. Chichester: Wiley, 167-186. 
Weber, G.W. and Bookstein, F.L., 2011. Virtual Anthropology: A guide to a new interdisciplinary field. New York: Springer.

Wells, J.D. and LaMotte, L.R., 2001. Estimating the post-mortem interval. In: J.H. Byrd and J.L. Castner, eds. Forensic Entomology: The Utility of Arthropods in Legal Investigations. Boca Raton: CRC Press, 263-285.

White, T.D., 1992. Prehistoric Cannibalism at Mancos 5MTUMR-2346. Princeton: Princeton University Press.

Xing, L., Roberts, E.M., Harris, J.D., Gingras, M.K., Ran, H., Zhang, J., Xu, X., Burns, M.E., and Dong, Z., 2013. Novel insect traces on a dinosaur skeleton from the Lower Jurassic Lufeng Formation of China. Palaeogeography, Palaeoclimatology, Palaeoecology, 388, 58-68.

Zanetti, N.I., Visciarelli, E.C., and Centeno, N.D., 2014. Taphonomic marks on pig tissue due to cadaveric Coleoptera activity under controlled conditions. Journal of Forensic Sciences, 59, 997-1001.

Zanetti, N.I., Visciarelli, E.C., and Centeno, N.D., 2016a. Biological strategies of Dermestes maculatus De Geer (Coleoptera: Dermestidae) at larval stages in different temperatures. Neotropical Entomology, 45, 652-657.

Zanetti, N.I., Visciarelli, E.C., and Centeno, N.D., 2016b. The effect of temperature and laboratory rearing conditions on the development of Dermestes maculatus (Coleoptera: Dermestidae). Journal of Forensic Sciences, 61, 375-381.

Zhantiev, R.D., 2009. Ecology and classification of dermestid beetles (Coleoptera, Dermestidae) of the Palaearctic fauna. Entomological Review, 89, 157-174. 


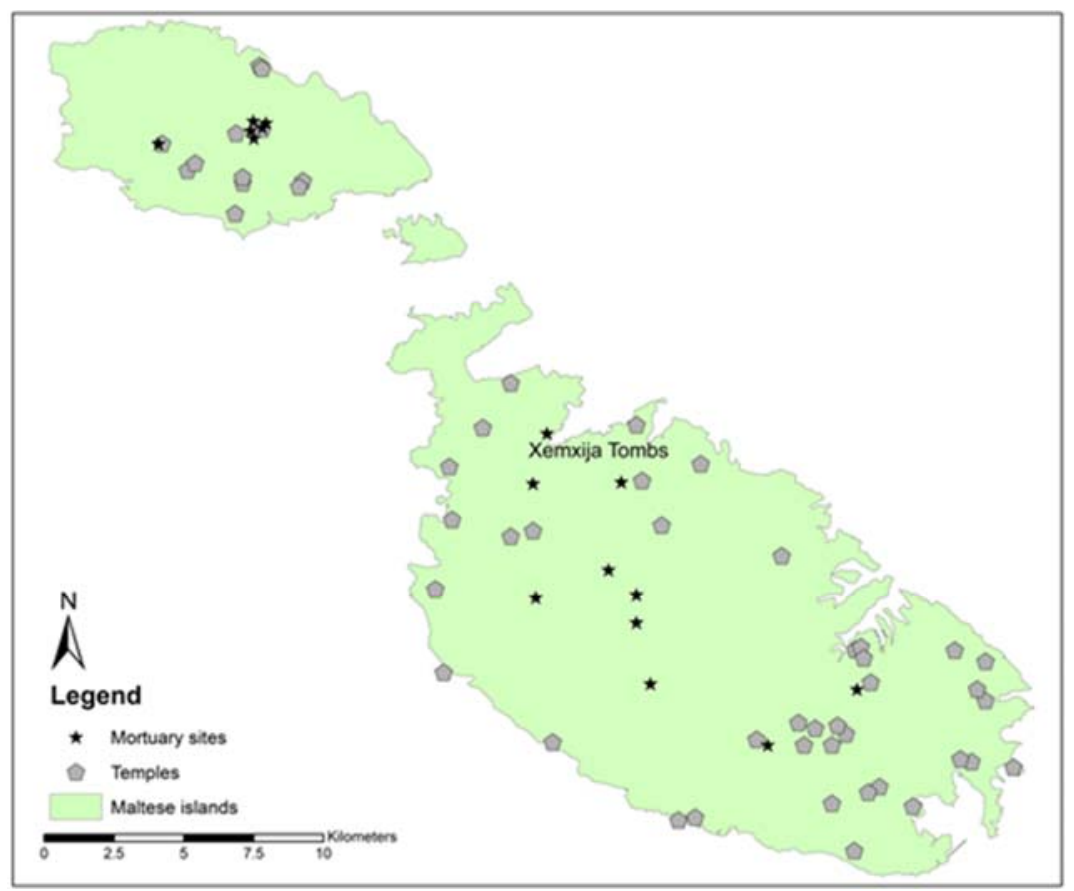

Figure 1: Location of Xemxija tombs.

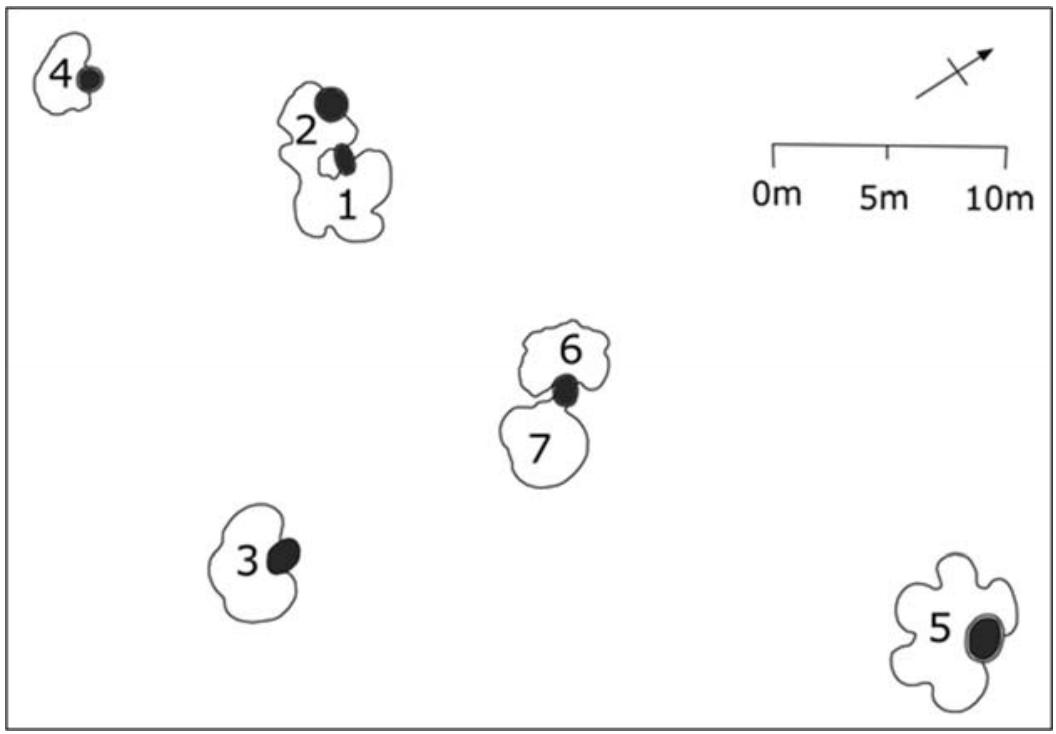

Figure 2: Plan of the Xemxija tombs (after Trump 2002, 163). 


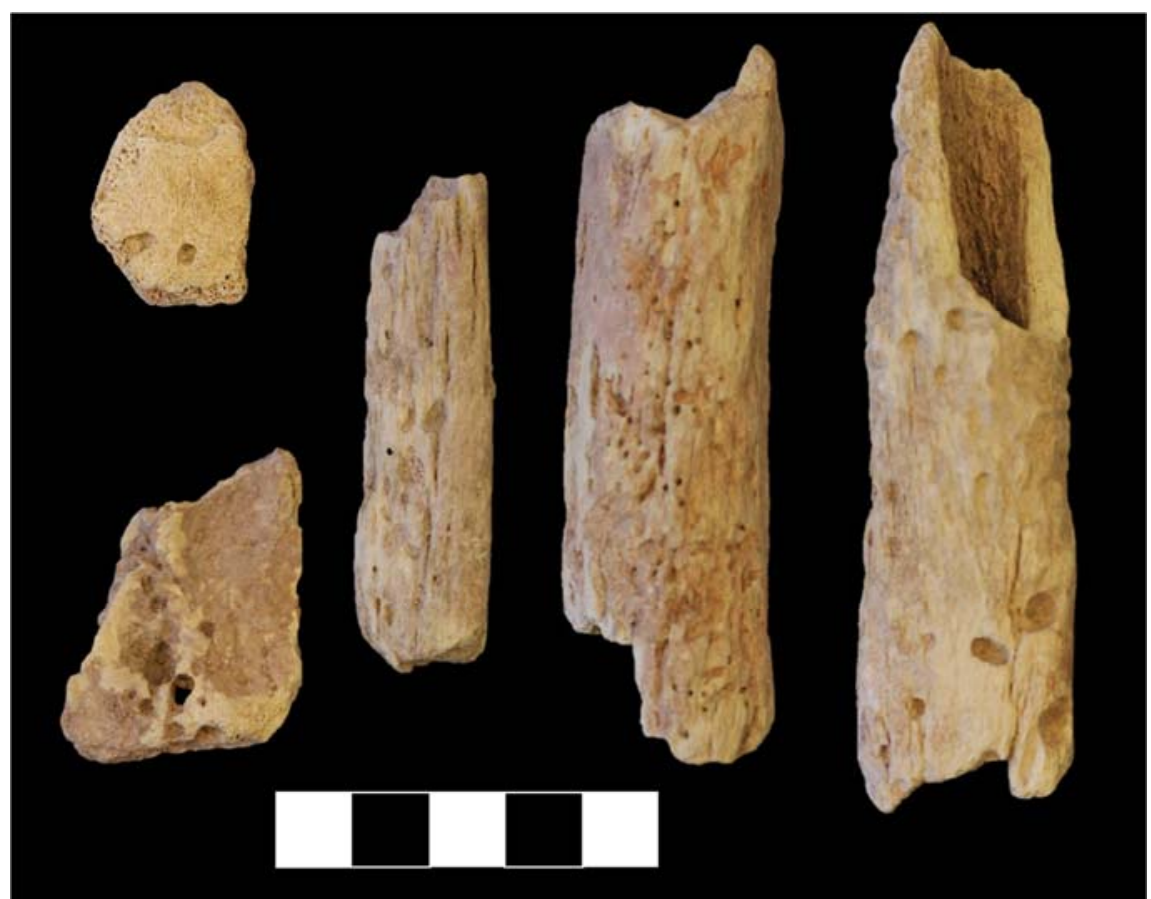

Figure 3: From left to right, XEM11081 (ectocranial aspect), XEM6626 (endocranial aspect), XEM10048, XEM477, XEM8720. 

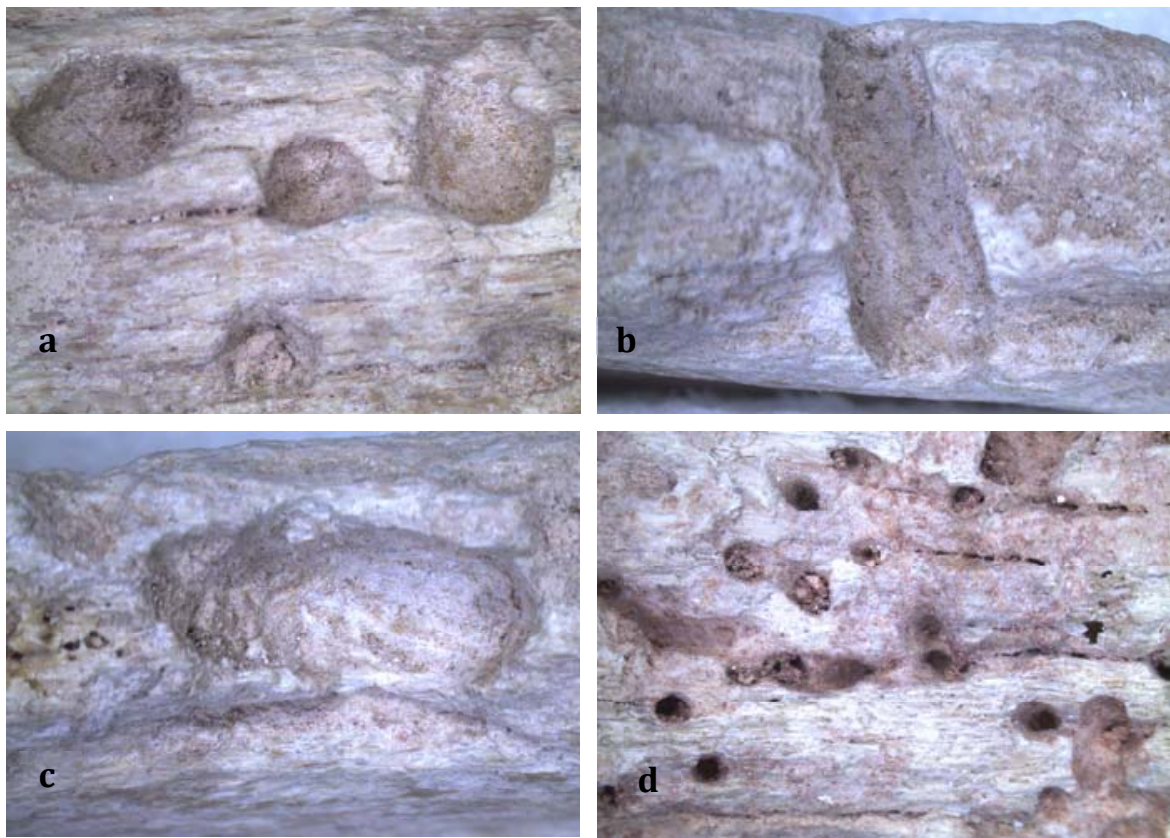

Figure 4: types of beetle modifications observed on Xemxija human remains; a: circular hemispherical pits (XEM8720); b: deep bore truncated by fragmentation (XEM8895); c: deep bore excavated into fragmentation margin (XEM8895); d: furrows between incipient bores (XEM477). 


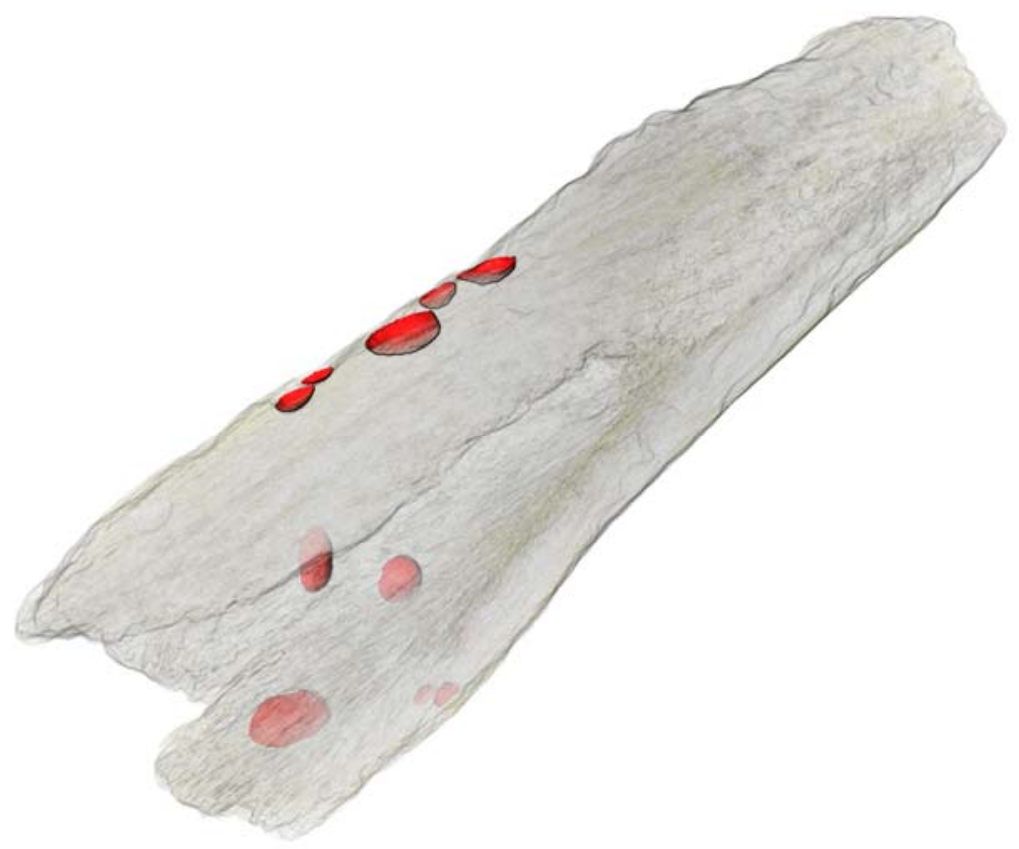

Figure 5: 3D reconstruction of a human femur from Xemxija tombs (XEM8720) with pupal chambers on the distal aspect of the element segmented and modelled in red.

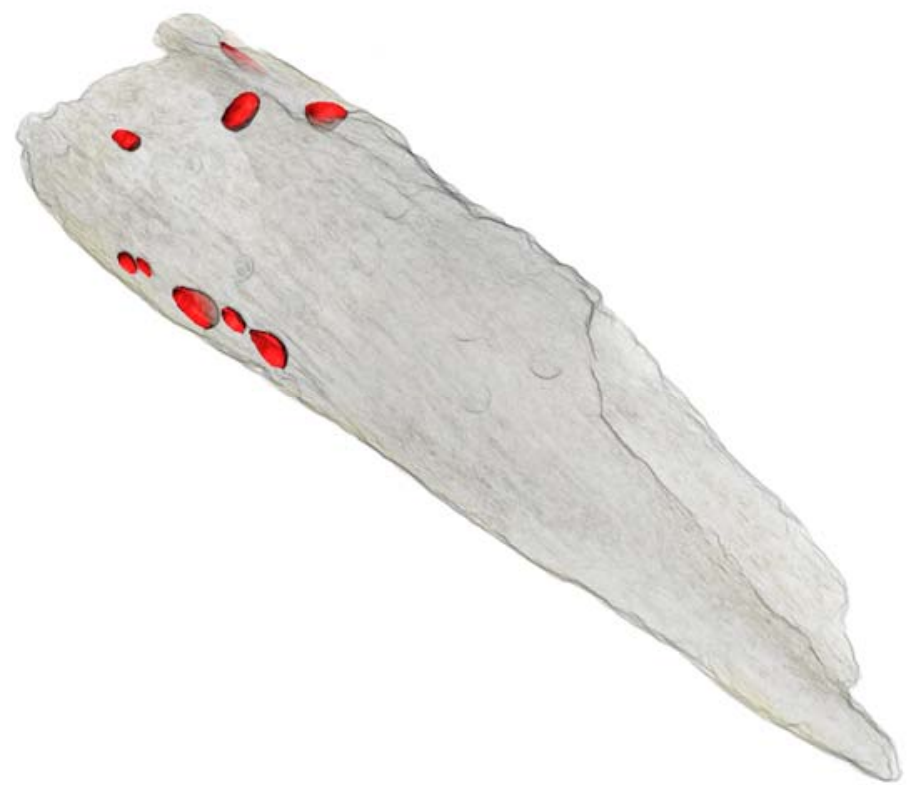


Figure 6: 3D reconstruction of a human femur from Xemxija tombs (XEM8720) with pupal chambers on the proximal aspect of the element segmented and modelled in red.
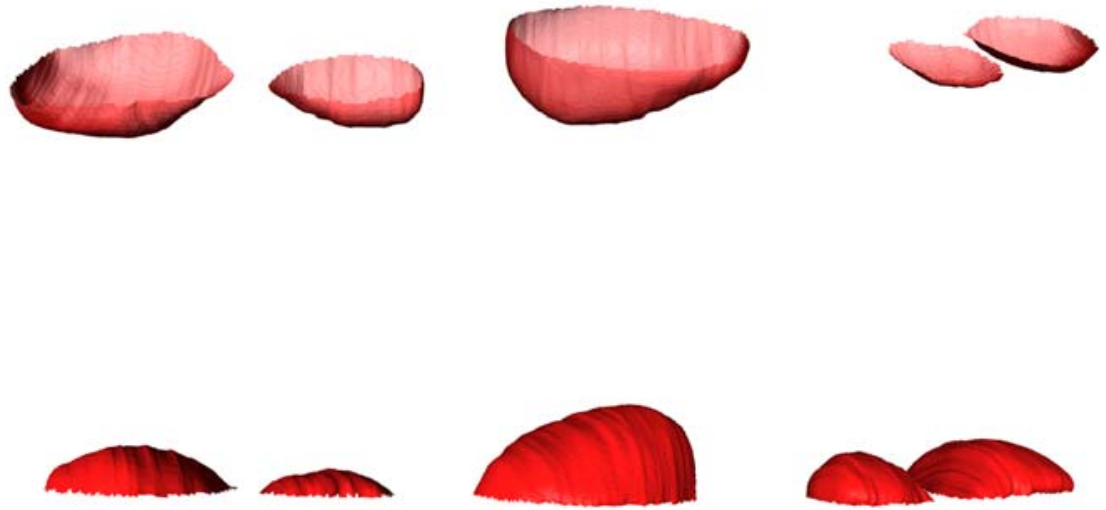

Figure 7: Lateral and laterodorsal views of segmented pupal chambers showing ovate morphology with varying size and depth. 